\title{
BREAST CANCER IN YOUNG WOMEN: PATHOLOGIC AND IMMUNOHISTOCHEMICAL FEATURES
}

\author{
Ivan Erićc ${ }^{1,2}$, Anamarija Petek Erić ${ }^{1,2}$, Jozo Kristek $^{1,2}$, Ivan Koprivčić ${ }^{2}$ and Marko Babić ${ }^{2}$ \\ ${ }^{1}$ Faculty of Medicine, Josip Juraj Strossmayer University of Osijek, Osijek, Croatia; \\ ${ }^{2}$ Osijek University Hospital Centre, Osijek, Croatia
}

\begin{abstract}
SUMMARY - A young woman with breast cancer is considered to be a woman younger than 40 . According to the literature, breast cancer in the population of young women usually is of a higher histologic grade, unfavorable hormonal status, and overall higher mortality rate when compared with breast cancer occurring in older population. We compared pathologic and immunohistochemical features of breast carcinoma in women under 40 years of age with the respective features in women over 60 years of age. The following parameters were observed in these two groups: tumor size, lymph node status, histologic grade, hormonal receptor status, Ki-67 prognostic index, Her2/neu status, and histologic type of the tumor. Early onset breast carcinoma was found to have a higher frequency of tumor grade 3 (29\% vs. $17 \%$ ) and estrogen receptor negativity ( $45 \%$ vs. $23 \%)$. In the group of young women, breast carcinoma was mostly multicentric (23\% vs. 5\%), triple-negative (32\% vs. 10\%), and was found to have higher proliferation index Ki-67 (25\% vs. 10\%). Our results confirmed differences between the young and older groups of patients. In the group of young women, we found predominantly unfavorable prognostic parameters of the disease.
\end{abstract}

Key words: Breast neoplasms; Female; Lymph codes; Croatia

\section{Introduction}

Breast cancer is a global public health issue. It is the most common malignancy in women and the most common mortality factor in the population of women. Due to the expansion of novel therapeutic options, from surgical and oncologic perspective, and with greater potential of recovery, breast cancer is one of the most widely researched malignancies in the past twenty years. Young women with breast cancer are considered to be those under 40 years of age ${ }^{1,2}$. In this population, breast carcinoma is the most common malignant disease and has the greatest mortality, although the rate of the total number of breast cancer cases is

Correspondence to: Ivan Erić, MD, Osijek University Hospital Centre, J. Huttlera 4, HR-31000 Osijek, Croatia

E-mail: ivaneric1@gmail.com

Received February 2, 2017, accepted March 6, 2017
$6 \%{ }^{3}$. Numerous clinical studies have confirmed that breast cancer in young women has a higher histologic grade, unfavorable hormonal status, and overall higher death rate compared to the older population of wom$\mathrm{en}^{4-6}$. This leads to a conclusion that treatment approach should be radical. Current treatment approach to breast carcinoma is multimodal. Surgical procedure must ensure removal of malignancy with an exact staging of axillary lymph nodes. Surgical treatment is essential in therapeutic approach to breast carcinoma, however, several main issues such as disease recurrence and distant metastases persist. Therefore, radiotherapy and chemotherapy (adjuvant or neoadjuvant) are inherent part in the treatment of breast carcinoma ${ }^{7-9}$. The aim of this study was to compare the characteristics of breast cancer in a group of young women with a group of postmenopausal women and confirm the higher malignant potential of cancer in the population of young women. 


\section{Materials and Methods}

In this retrospective study, data were collected from medical charts of patients that had undergone surgical treatment between 2002 and 2010 at the Department of Surgery, Osijek University Hospital Centre in Osijek, Croatia. Patients were divided into two groups. The first group consisted of young women (YW) less than 40 years of age. The second group encompassed postmenopausal women (PMW) over 60 years of age and according to our data with no menstrual cycle. These two groups were compared according to the following parameters: tumor size, lymph node status, histologic grade, hormonal receptor status, $\mathrm{Ki}-67$ prognostic index, Her2/neu status, and histologic type of tumor. All patients included in the study had complete documentation. Those with incomplete documentation and data were excluded from the study. All study patients had tumor stage 1-3. Patients with positive distant metastasis (M) at the time of diagnosis were not included in the study.

We collected data on 166 patients, 79 YW (47.6\%), median age 37 (range, 33-39) years, and 87 PMW (52.4\%), median age 69 (range, 65-73) years.

Breast tissue was fixed, paraffin embedded and cut into 5- $\mu \mathrm{m}$ sections. Then it was stained and observed under a microscope. Hormonal status, Her2/neu status and Ki 67 were determined by immunochemical staining. Among patients with Her2/neu 2+, the FISH method was performed to determine whether the patient was Her2/neu positive or negative.

We used the TNM classification from the American Joint Committee on Cancer Staging System for Breast Cancer from 2010. Histologic grading of breast carcinoma was performed by Elston and Ellis method.

Statistical analysis was performed with SPSS 13.0 (Chicago, IL). On comparison of patient groups, Fisher exact test, $\chi 2$-test and Mann-Whitney $U$ test were used. The level of statistical significance was set at $\mathrm{p}<0.05$.

\section{Results}

Data on 166 patients were collected, $79(47.6 \%)$ in the YW group, median age 37 (range, 33-39) years, and $87(52.4 \%)$ in the PMW group, median age 69 (range, 65-73) years (Table 1). There was no significant difference in operated side between YW (right 40\%-
50.4\%; left 39\%-49.6\%) and PMW (right 44\%-50.4\%; left 43\%-49.6\%).

Invasive ductal carcinoma was the most frequent histologic type of tumor in both groups. In the YW group, $56(70.9 \%)$ tumors were histologically invasive ductal carcinoma, whereas in the PMW group 52 (59.8\%) patients had this type of tumor. Invasive lobular carcinoma was found to be the second most common type in both patient groups in our sample.

Regarding the size of tumor, there were no statistically significant differences between patient groups in T1-T3 sizes. The T4 tumor size (any size with the skin or chest wall spread) was recorded in nine (10.3\%) PMW group patients and three (3.8\%) YW group patients $\left(\chi^{2}\right.$-test, $\left.\mathrm{p}=0.036\right)$. There were no statistically significant between-group differences in lymph node status and N1-N3 parameters.

Negative estrogen receptor status was found in 36 (45.6\%) YW and 20 (23\%) PMW patients (Fisher exact test, $\mathrm{p}=0.003$ ). Positive estrogen receptor status was found to be more positive in PMW group as compared with YW group: 67 (77\%) versus 43 (54.4\%); however, these differences were not statistically significant (Table 1).

Negative progesterone receptor status had 35 (44.3\%) WY patients and 33 (37\%) PMW patients. Positive progesterone receptor status was found in 44 (55.7\%) YW patients and 54 (62.1\%) PMW patients. Differences in progesterone receptor status between the groups were not statistically significant (Fisher exact test, $\mathrm{p}=0.433$ ).

The Her2/neu receptor status was also investigated in both patient groups. As shown in Table 1, there were no statistically significant between-group differences in either positive or negative Her2/neu status.

The rate of triple-negative breast carcinoma (negative estrogen and progesterone receptors, negative Her2/neu) was found to be significantly higher in YW patients as compared with PMW patients: 25 (32.1\%) versus nine (10.3\%) (Fisher exact test, $\mathrm{p}=0.001$ ) (Table 1).

The Ki-67 proliferation index was significantly lower in PMW group (median 10.4\%; interquartile range 5\%-25\%) as compared with YW group (median $25 \%$; interquartile range $11 \%$ to up to $48 \%$ ) (MannWhitney U test, $\mathrm{p}<0.001$ ).

Modified radical mastectomy with axillary lymph node dissection was the preferred operation type in 
Table 1. Pathologic and immunohistochemical features

\begin{tabular}{|c|c|c|c|c|}
\hline & \multicolumn{3}{|c|}{ Age group (years) } & \multirow{2}{*}{$\mathrm{p}^{*}$} \\
\hline & $<40$ & $>60$ & Total & \\
\hline \multicolumn{5}{|l|}{ Affected side, n (\%) } \\
\hline right & $40(50.6)$ & $44(50.6)$ & $84(50.6)$ & \multirow{2}{*}{$>0.950^{\dagger}$} \\
\hline left & $39(49.4)$ & $43(49.4)$ & $82(49.4)$ & \\
\hline \multicolumn{5}{|l|}{ Histologic type, $\mathrm{n}(\%)$} \\
\hline ductal invasive & $56(70.9)$ & $52(59.8)$ & $108(65.1)$ & \multirow{3}{*}{$0.244^{*}$} \\
\hline lobular invasive & $11(13.9)$ & $15(17.2)$ & $26(15.7)$ & \\
\hline other & $12(15.2)$ & $20(23)$ & $32(19.3)$ & \\
\hline \multicolumn{5}{|l|}{ Tumor size (T), n (\%) } \\
\hline $\mathrm{T} 1 \leq 2 \mathrm{~cm}$ & $39(49.4)$ & $27(31)$ & $66(39.8)$ & \multirow{4}{*}{$0.036^{*}$} \\
\hline $\mathrm{T} 2>2 \mathrm{~cm} \leq 5 \mathrm{~cm}$ & $30(38)$ & $46(52.9)$ & $76(45.8)$ & \\
\hline $\mathrm{T} 3>5 \mathrm{~cm}$ & $7(8.9)$ & $5(5.7)$ & $12(7.2)$ & \\
\hline T4 any size with skin or chest wall spread & $3(3.8)$ & $9(10.3)$ & $12(7.2)$ & \\
\hline Positive lymph nodes, $\mathrm{n}(\%)$ & $49(62)$ & $45(51.7)$ & $94(56.6)$ & $0.211^{*}$ \\
\hline \multicolumn{5}{|l|}{ Lymph node status, $\mathrm{n}(\%)$} \\
\hline 1-3 lymph nodes & $30(61.2)$ & $17(37.8)$ & $47(50)$ & \multirow{3}{*}{$0.057^{*}$} \\
\hline 4-9 lymph nodes & $13(26.5)$ & $16(35.6)$ & $29(30.9)$ & \\
\hline$\geq 10$ lymph nodes & $6(12.2)$ & $12(26.7)$ & $18(19.1)$ & \\
\hline \multicolumn{5}{|l|}{ Estrogen status, $\mathrm{n}(\%)$} \\
\hline negative & $36(45.6)$ & $20(23)$ & $56(33.7)$ & \multirow{2}{*}{$0.003^{+}$} \\
\hline positive & $43(54.4)$ & $67(77)$ & $110(66.3)$ & \\
\hline \multicolumn{5}{|l|}{ Progesterone status, n (\%) } \\
\hline negative & $35(44.3)$ & $33(37.9)$ & $68(41)$ & \multirow{2}{*}{$0.433^{+}$} \\
\hline positive & $44(55.7)$ & $54(62.1)$ & $98(59)$ & \\
\hline \multicolumn{5}{|l|}{ HER-2/neu status, n (\%) } \\
\hline negative & $60(75.9)$ & $69(79.3)$ & $129(77.7)$ & \multirow{2}{*}{$0.709^{\dagger}$} \\
\hline positive & $19(24.1)$ & $18(20.7)$ & $37(22.3)$ & \\
\hline Triple-negative, $\mathrm{n}(\%)$ & $25(32.1)$ & $9(10.3)$ & $34(20.6)$ & $0.001^{\dagger}$ \\
\hline Ki67, median (25\%-75\%) & $\begin{array}{l}25 \\
(11-48)\end{array}$ & $\begin{array}{l}10.4 \\
(5-25)\end{array}$ & $\begin{array}{l}19.3 \\
(5-33)\end{array}$ & $<0.001^{\ddagger}$ \\
\hline \multicolumn{5}{|l|}{ Type of surgical procedure, $\mathrm{n}(\%)$} \\
\hline mastectomy sec Madden & $52(65.8)$ & $66(75.9)$ & $118(71.1)$ & \multirow{2}{*}{$0.173^{\dagger}$} \\
\hline breast conserving resection & $27(34.2)$ & $21(24.1)$ & $48(28.9)$ & \\
\hline Multicentric tumor position, n (\%) & $18(23.1)$ & $5(5.7)$ & $23(13.9)$ & $0.001^{\dagger}$ \\
\hline \multicolumn{5}{|l|}{ Histologic grade, $\mathrm{n}(\%)$} \\
\hline I & $13(16.5)$ & $33(39.3)$ & $46(28.2)$ & \multirow{3}{*}{$0.004^{*}$} \\
\hline II & $43(54.4)$ & $36(42.9)$ & $79(48.5)$ & \\
\hline III & $23(29.1)$ & $15(17.9)$ & $38(23.3)$ & \\
\hline
\end{tabular}

* $\chi^{2}$-test; ${ }^{\dagger}$ Fisher exact test; ${ }^{\ddagger}$ Mann Whitney U test

118 (71.1\%) patients, while the breast conserving surgery with axillary lymph node dissection was preferred in 48 (28.9\%) patients, equally in both age groups.
We found a significantly higher incidence of multicentric tumor in YW patients $(\mathrm{n}=18 ; 23.15 \%)$ as compared with PMW patients $(\mathrm{n}=5 ; 5.7 \%)$ (Fisher exact test, $\mathrm{p}=0.001)$ (Table 1 ). 
The majority of patients, 79 (48.5\%) of them, had histologic grade 2. Grade 3 was found in 38 (23.3\%) patients and the distribution was significantly higher in the YW patient group (Fisher exact test, $\mathrm{p}=0.004$ ) (Table 1).

\section{Discussion}

In developed countries, 5\%-7\% of all patients with breast cancer are younger than 40 years of age ${ }^{3}$. In China, young patients with breast cancer account for $5 \%-13 \%$ of all breast cancer cases ${ }^{10}$. Breast cancer that occurs in younger age is considered to be different than the one in older patients. These carcinomas tend to have more aggressive biologic nature, higher tumor grade, and higher proliferation fraction with more vascular invasion than the same malignancies found in older women ${ }^{4}$. Young patients with breast cancer are faced with numerous psychological challenges, with a greater incidence of radical mastectomy, premature menopause, and infertility ${ }^{11}$. In young patients, the disease has worse prognosis in terms of overall survival and disease recurrence ${ }^{12}$. Various studies identified young age as an independent factor of poor disease prognosis $^{13,14}$.

In our sample, we found no difference in cancer laterality according to patient age (YW and PMW groups). In a study on 687 patients, there was no difference in breast cancer laterality in general and when divided to age subgroups ${ }^{15}$. Invasive ductal carcinoma was the most frequent histologic type of tumor. The second most common type was invasive lobular carcinoma. Different studies confirmed invasive ductal carcinoma as one of the most frequent cancers in general and among women under 40 years of age ${ }^{16,17}$. A study conducted at the Mount Sinai Medical Center in New York found that younger patients had larger tumors with more nodal involvement ${ }^{6}$. However, we found no difference in these parameters, which is consistent with the findings reported by Colleoni et al. ${ }^{18}$.

We found a significantly higher negative estrogen receptor status in the YW patient group, but there were no differences in estrogen positive or progesterone status. Histology grade 3 was significantly more frequent in the group of young patients. Gnerlich et al. found that young women had tumors with negative estrogen and progesterone receptor status but accompanied with higher histologic grade ${ }^{19}$. These character- istics are usually associated with more aggressive tumors, poorer prognosis, and linked with $\mathrm{Her} 2 /$ neu overexpression.

Her2/neu overexpression has been reported in tumors developing at a younger age and considered to be part of aggressive immunophenotype in breast cancer, especially with lymph node metastase ${ }^{20}$. On the other hand, Anders et al. found that Her2/neu status did not prove to be an independent factor of poor prognosis in young patients with cancer ${ }^{21}$. We found no difference in Her2/neu overexpression between patient groups in our sample. However, we did find a significantly higher proportion of triple-negative tumor (32\%) in the YW group. Triple-negative tumors were overrepresented among young women with breast cancer with a rate of $25 \%{ }^{22}$. These carcinomas, particularly in younger women, are supposed to be associated with BRCA 1 germline mutations and represent the most aggressive phenotype that is linked to poor prognosis ${ }^{23}$.

Many studies have suggested that $\mathrm{Ki}-67$ is a predictive factor of the disease outcome in hormone positive tumors ${ }^{24}$. Munzone et al. demonstrated that Ki-67 might predict response to chemotherapeutic treatment and was associated with disease prognosis in hormone negative patient groups ${ }^{25}$. In our sample, Ki-67 was found to be $25 \%$, which is a high value pointing to poor prognosis of the disease in our YW group. In our YW group, 23\% of all tumors had the multicentric position as the final pathologic finding. Multicentric tumors have been recognized as highly significant predictors of reduced survival, increased local relapse, and distant metastases ${ }^{26}$. The presence of multicentric tumor could be the reason for choosing the radical mastectomy approach. However, with adjuvant chemoradiotherapy, there is no difference in overall survival and disease-free survival between mastectomy and breast-sparing resection ${ }^{27}$.

\section{Conclusion}

Even though breast carcinoma in young women has a relatively small proportion (6\%), it does not reduce its significance and impact on public health. This research ascertained that breast carcinoma in young women ( $<40$ years of age) is different from breast carcinoma occurring in older women ( $>60$ years of age). The main differences are negative estrogen receptor status, multicentric position, higher histologic grade, 
triple-negative tumors, and higher Ki-67 index. These features have been found to be the key attributes for aggressive disease course with increased probability of poor overall survival and disease-free survival.

\section{References}

1. Collins LC, Marotti JD, Gelber S, Cole K, Ruddy K, Kereakoglow S, Brachtel EF, Schapira L, Come SE, Winer EP, Partridge AH. Pathologic features and molecular phenotype by patient age in a large cohort of young women with breast cancer. Breast Cancer Res Treat. 2012 Feb;131(3):1061-6. doi: 10.1007/s10549-011-1872-9. Epub 2011 Nov 13.

2. Zhou P, Recht A. Young age and outcome for women with earlystage invasive breast carcinoma. Cancer. 2004;101:1264-74.

3. Brinton LA, Sherman ME, Carreon JD, Anderson WF. Recent trends in breast cancer among younger women in the United States. J Natl Cancer Inst. 2008 Nov 19;100(22):1643-8. doi: 10.1093/jnci/djn344. Epub 2008 Nov 11.

4. Walker RA, Lees E, Webb MB, Dearing SJ. Breast carcinomas occuring in young women ( $<35$ years) are different. Br J Cancer. 1996;74:1796-800.

5. Chung M, Chang HR, Bland KI, Wanebo HJ. Younger women with breast carcinoma have poorer prognoses than older women. Cancer. 1996;77:97-103.

6. Gajdos C, Tarrter PI, Bleiweiss IJ, Bodian C, Brower ST. Stage 0 to stage III breast cancer in young women. J Am Coll Surg. 2000;190:523-9.

7. Fisher B, Bryant J, Wolmark N, Mamounas E, Brown A, Fisher ER, et al. Effect of preoperative chemotherapy on the outcome of women with operable breast cancer. J Clin Oncol. 1998 Aug;16(8):2672-85.

8. Early Breast Cancer Trialists' Collaborative Group (EBCTCG), Darby S, McGale P, Correa C, Taylor C, Arriagada R, Clarke $\mathrm{M}$, et al. Effect of radiotherapy after breast-conserving surgery on 10-year recurrence and 15-year breast cancer death: metaanalysis of individual patient data for 10,801 women in 17 randomised trials. Lancet. 2011 Nov 12;378(9804):1707-16.

9. Schwartz GF, Birchansky CA, Komarnicky LT, Mansfield CM, Cantor RI, Biermann WA, et al. Induction chemotherapy followed by breast conservation for locally advanced carcinoma of the breast. Cancer. 1994 Jan 15;73(2):362-9.

10. Meng J. Clinical analysis for young female patients with breast cancer. Chinese J Clin Oncol. 2006;33:1316-9.

11. Ali A, Fergus K, Wright FC, Pritchard KI, Kiss A, Warner E. The impact of a breast cancer diagnosis in young women on their relationship with their mothers. Breast. 2014;23:50-5.

12. Han W, Kim SW, Park IA, Kang D, Kim SW, Youn YK, et al. Young age: an independent risk factor for disease-free survival in women with operable breast cancer. BMC Cancer. $2004 \mathrm{Nov}$ $17 ; 4: 82$.

13. Chen HL, Zhou MQ, Tian W, Meng KX, He HF. Effect of age on breast cancer patient prognoses: a population-based study using the SEER 18 database. PLoS One. 2016 Oct 31;11(10):e0165409. doi: 10.1371.
14. Fredholm H, Magnusson K, Lindström LS, Garmo H, Fält SE, Lindman $\mathrm{H}$, et al. Long-term outcome in young women with breast cancer: a population-based study. Breast Cancer Res Treat. 2016 Nov;160(1):131-43. Epub 2016 Sep 13.

15. Magid H Amer. Genetic factors and breast cancer laterality. Cancer Manag Res. 2014;6:191-203.

16. Bertheau P, Steinberg SM, Cowan K, Merino MJ. Breast cancer in young women: clinicopathologic correlation. Semin Diagn Pathol. 1999 Aug;16(3):248-56.

17. Rosenberg LU, Magnusson C, Lindström E, Wedrén S, Hall P, Dickman PW. Menopausal hormone therapy and other breast cancer risk factors in relation to the risk of different histological subtypes of breast cancer: a case-control study. Breast Cancer Res. 2006;8(1):R11-10.1186/bcr1378.

18. Colleoni M, Rotmensz N, Robertson C, Orlando L, Viale G, Renne G, et al. Very young women ( $<35$ years) with operable breast cancer: features of disease at presentation. Ann Oncol. 2002;13:273-9.

19. Gnerlich JL, Deshpande AD, Jeffe DB, Sweet A, White N, Margenthaler JA. Elevated breast cancer mortality in young women ( $<40$ years) compared with older women is attributed to poorer survival in early stage disease. J Am Coll Surg. 2009 Mar;208(3):341-7. doi: 10.1016/j.jamcollsurg.2008.12.001

20. Agrup M, Stål O, Olsen K, Wingren S. C-erbB-2 overexpression and survival in early onset breast cancer. Breast Cancer Res Treat. 2000 Sep;63(1):23-9.

21. Anders CK, Hsu DS, Broadwater G, Acharya CR, Foekens JA, Zhang Y, et al. Young age at diagnosis correlates with worse prognosis and defines a subset of breast cancers with shared patterns of gene expression. J Clin Oncol. 2008;26:3324-30.

22. Carvalho FM, Bacchi LM, Santos PP, Bacchi CE. Triple-negative breast carcinomas are a heterogeneous entity that differs between young and old patients. Clinics (Sao Paulo). 2010; 65(10):1033-6.

23. Arnes JB, Begin LR, Stefansson I, Brunet JS, Nielsen TO, Foulkes WD. Expression of epidermal growth factor receptor in relation to BRCA1 status, basal like markers and prognosis in breast cancer. J Clin Pathol. 2009;62:139-46. doi: 10.1136/ jcp.2008.056291

24. Yoshioka T, Hosoda M, Yamamoto M, Taguchi K, Hatanaka KC, Takakuwa E, et al. Prognostic significance of pathologic complete response and Ki67 expression after neoadjuvant chemotherapy in breast cancer. Breast Cancer. 2015 Mar;22(2): 185-91.

25. Munzone E, Botteri E, Sciandivasci A, Curigliano G, Nole F, Mastropasqua $\mathrm{M}$, et al. Prognostic value of $\mathrm{Ki}-67$ labeling index in patients with node-negative, triple-negative breast cancer. Breast Cancer Res Treat. 2012;134:277-82.

26. Weissenbacher TM, Zschage M, Janni W, Jeschke U, Dimpfl T, Mayr D, et al. Multicentric and multifocal versus unifocal breast cancer: is the tumor-node-metastasis classification justified? Breast Cancer Res Treat. 2010 Jul;122(1):27-34.

27. Ordu C, McGuire K, Alco G, Nur Pilanci K, Koksal UI, E1büken $\mathrm{F}$, et al. The prognostic impact of molecular subtypes and very young age on breast conserving surgery in early stage breast cancer. Cureus. 2016 Jun 7;8(6):e633. 


\section{Sažetak}

\section{RAK DOJKE U MLADIH ŽENA: PATOLOŠKA I IMUNOHISTOKEMIJSKA OBILJEŽJA}

\section{Eric, A. Petek Erić, J. Kristek, I. Koprivčić i M. Babić}

Mladom ženom s rakom dojke smatra se žena mlađa od 40 godina. Prema literaturi rak dojke u populaciji mladih žena ima obično viši histološki stupanj i nepovoljan hormonski status. Puno je veći postotak smrtnosti u mladoj populaciji nego kada se karcinom javlja u starijoj životnoj dobi. Usporedili smo patološka i imunohistokemijska obilježja karcinoma dojke kod žena ispod 40 godina s odgovarajućim obilježjima među ženama iznad 60 godina. Sljedeći parametri su promatrani kod ove dvije skupine: veličina tumora, stanje limfnih čvorova, histološki gradus, status hormonskih receptora, prognostički indeks Ki-67, status Her2/neu i histološki tip tumora. Za karcinom dojke kod mladih žena utvrđeno je da ima veću učestalost tumora histološkog gradusa 3 (29\% prema 17\%) i negativnog statusa estrogenskih receptora (45\% prema 23\%). U skupini mladih žena rak dojke je uglavnom multicentričan (23\% prema 5\%), trostruko negativan (32\% prema 10\%) i ustanovljeno je da ima veći proliferacijski indeks Ki-67 (25\% prema 10\%). Naši rezultati potvrđuju razlike između mlade i starije skupine bolesnica. U skupini mladih žena utvrđeni su pretežito nepovoljni prognostički parametri bolesti.

Ključne riječi: Dojka, tumori; Ženska osoba; Limfni čvorovi; Hrvatska 